\title{
Synthetic Studies toward Hennoxazole A. Use of a Selective Bisoxazole Alkylation as the Key Fragment Coupling
}

\section{Citation}

E. Smith, Thomas, and Emily P. Balskus. 2002. "Synthetic Studies Toward Hennoxazole A. Use of a Selective Bisoxazole Alkylation as the Key Fragment Coupling." HETEROCYCLES 57 (7): 1219. doi:10.3987/com-02-9480.

\section{Published Version}

doi:10.3987/COM-02-9480

\section{Permanent link}

http://nrs.harvard.edu/urn-3:HUL.InstRepos:33946915

\section{Terms of Use}

This article was downloaded from Harvard University's DASH repository, and is made available under the terms and conditions applicable to Other Posted Material, as set forth at http:// nrs.harvard.edu/urn-3:HUL.InstRepos:dash.current.terms-of-use\#LAA

\section{Share Your Story}

The Harvard community has made this article openly available.

Please share how this access benefits you. Submit a story.

\section{Accessibility}


HETEROCYCLES, Vol. 57, No. 7, 2002, pp. 1219-1225, Received, 25th March, 2002

SYNTHETIC STUDIES TOWARD HENNOXAZOLE A. USE OF A SELECTIVE BISOXAZOLE ALKYLATION AS THE KEY FRAGMENT COUPLING

Thomas E. Smith* and Emily P. Balskus

Department of Chemistry, Williams College, 47 Lab Campus Drive, Williamstown, MA 01267, USA. tsmith@williams.edu

\begin{abstract}
A model system for side chain fragment coupling to the core of hennoxazole $\mathrm{A}$ is investigated. Lateral metallation of a $\mathrm{C}_{13}$-TBS-protected bisoxazole, using lithium diethylamide, allows for selective and efficient alkylation at $\mathrm{C}_{15}$.
\end{abstract}

\title{
INTRODUCTION
}

Marine natural products containing the oxazole nucleus have drawn considerable attention recently (Figure 1). Synthetic studies of complex molecules containing isolated 2,4-disubstituted oxazole units such as the phorboxazoles, ${ }^{1}$ bisoxazoles such as the hennoxazoles ${ }^{2}$ and diazonamides, ${ }^{3}$ and trisoxazoles such as the ulapualides, ${ }^{4}$ have contributed methods for the assembly of these systems and have resulted in several total syntheses. The development of relatively mild oxazole-forming reaction sequences ${ }^{5}$ has

Figure 1. Oxazole-Containing Marine Natural Products

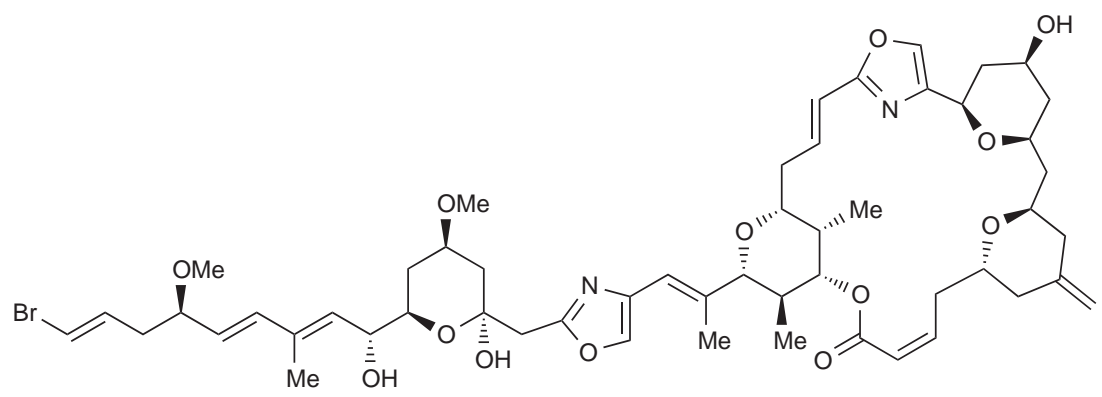

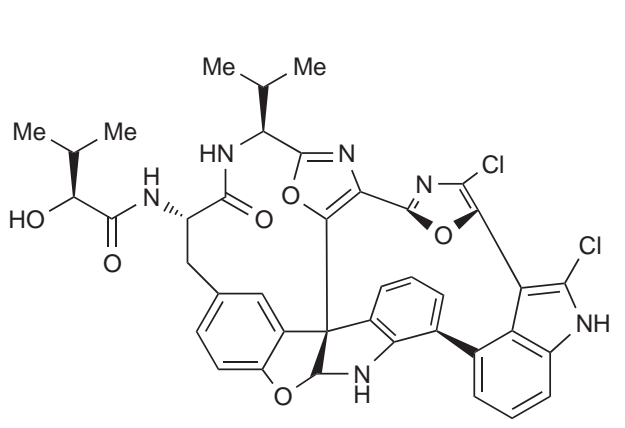

Diazonamide $A$

Phorboxazole B

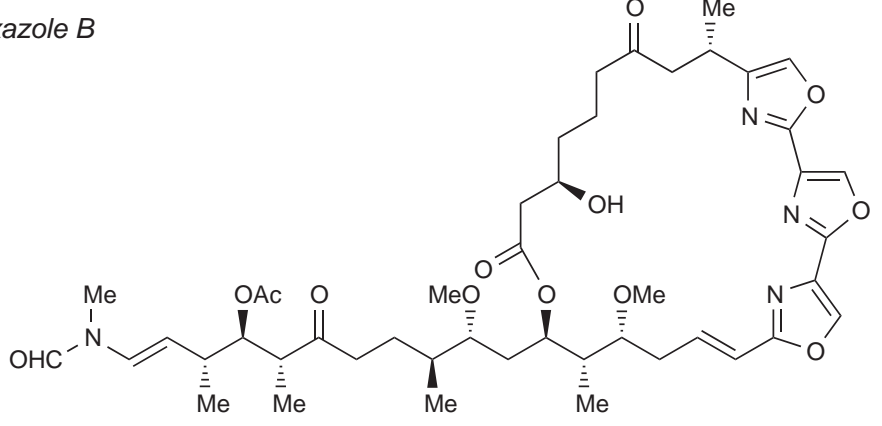


made the late-stage creation of these ring systems a common strategy—with cleavage of an oxazole ring frequently serving as the key disconnection back to major coupling fragments. ${ }^{6}$ Approaches involving end game functionalization of intact oxazole rings, however, provide the opportunity to use relatively simple oxazoles as starting materials and then efficiently carry these, practically inert, ${ }^{7}$ heterocycles through a variety of synthetic transformations. ${ }^{8}$ In consideration of these issues, our synthesis plan for hennoxazole A (1, Scheme 1) involves late-stage construction of the $C_{15}-C_{16}$ bond by metallation of a relatively elaborate bisoxazole (2) at the $\mathrm{C}_{15}$-methyl position, followed alkylation with an allylic halide $\mathrm{C}_{16}-\mathrm{C}_{25}$ side chain fragment (3). ${ }^{9}$

Scheme 1. Retrosynthetic Analysis for Hennoxazole A

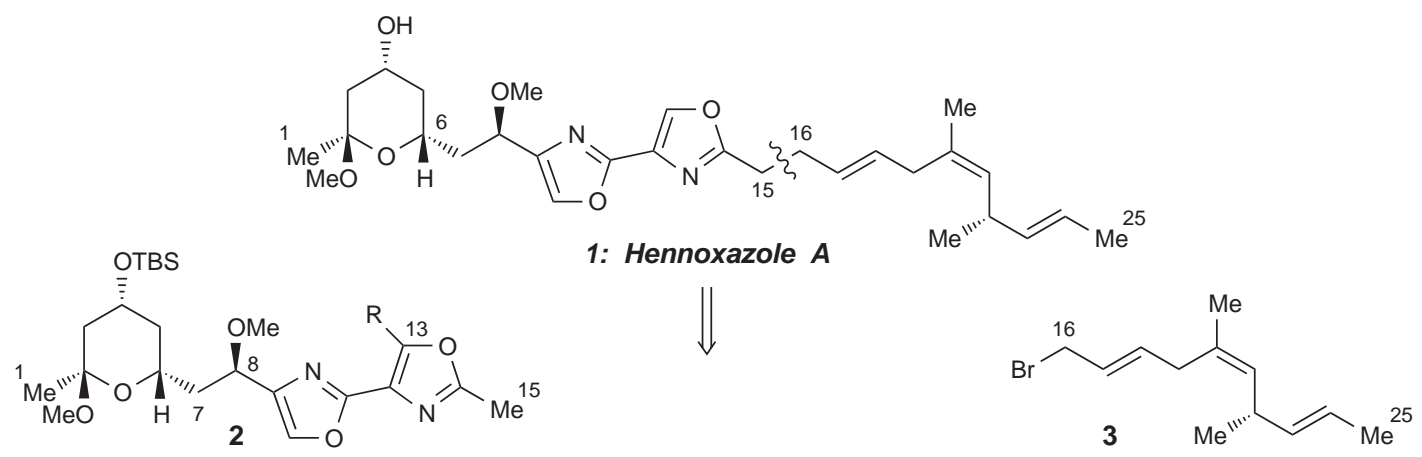

Synthetically useful lateral metallations of some 2-methyl-oxazole and -thiazole systems have been reported. ${ }^{10}$ If these rings are unsubstituted at $\mathrm{C}_{5}$, however, competitive deprotonation of the $\mathrm{C}_{5}$-ring hydrogen is frequently observed (Scheme 2). ${ }^{11}$ In fact, Williams has shown that bisoxazole 4 is lithiated with $n$-BuLi exclusively at the $\mathrm{C}_{5}$,-ring position, ${ }^{12}$ suggesting that alkylation of $\mathbf{2}$ at $\mathrm{C}_{15}$ may be problematic if $\mathrm{R}=\mathrm{H}$. Despite this result, previous work confronting a similar problem in the synthesis of phorboxazole, demonstrated that the regioselectivity of some oxazole deprotonations can be altered by the use of lithium diethylamide. ${ }^{13}$ As elaborated in the preceding communication, ${ }^{14}$ deprotonation of

Scheme 2. Oxazole and Bisoxazole Alkylations
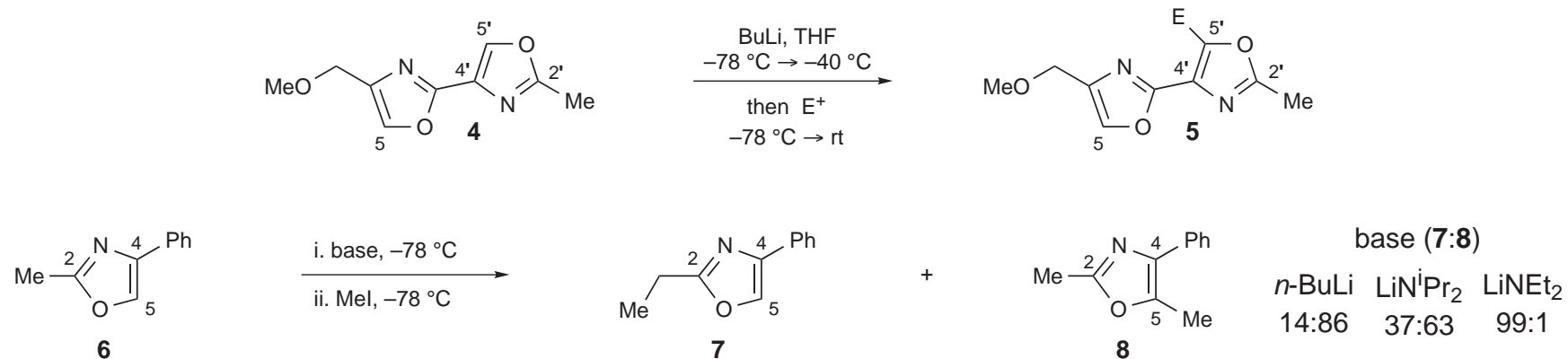

7

8

Mel
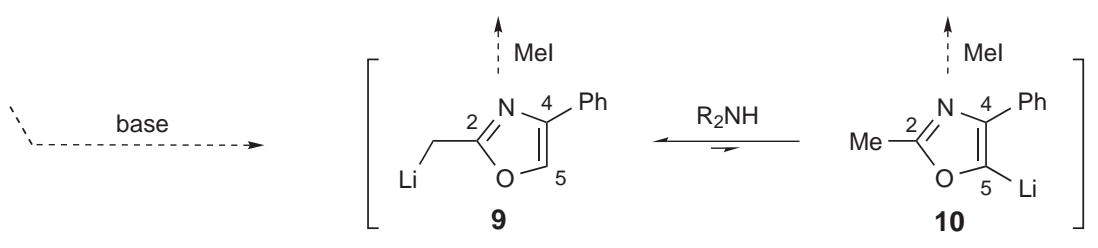
2-methyl-4-phenyloxazole (6) using $n$-BuLi at $-78{ }^{\circ} \mathrm{C}$ followed by alkylation with methyl iodide gives a 14:86 ratio of products $\mathbf{( 7 : 8 )}$ favoring ring methylation, while the use of $\mathrm{LiNEt}_{2}$ leads to alkylation solely at the $\mathrm{C}_{2}$-methyl site. This reversal of regioselectivity is thought to arise from the ability of diethylamine to mediate the low-temperature equilibration of a kinetic mixture of otherwise noninterconverting lithiated intermediates $\left(\mathbf{9}\right.$ and 10). ${ }^{15}$

Herein we report our results on a model fragment coupling for hennoxazole A using lithium diethylamide.

\section{RESULTS AND DISCUSSION}

To test the viability of our key side chain coupling strategy, we first prepared bisoxazole (13) as a model substrate (Scheme 3). Bisoxazole ester (11) ${ }^{16}$ was reduced with DIBAL-H in $\mathrm{CH}_{2} \mathrm{Cl}_{2}$ at low temperature to give aldehyde $(\mathbf{1 2})^{17}$ in quantitative yield. Dimethyl acetal (13) was then generated under Noyori conditions $^{18}$ in $93 \%$ yield. In results consistent with Williams' studies of $\mathbf{4},{ }^{12}$ treatment of bisoxazole (13) with $n$-BuLi led to deprotonation exclusively at the $\mathrm{C}_{13}$ ring position (hennoxazole numbering), with no deprotonation occurring at the $\mathrm{C}_{15}$-methyl group. For this substrate, replacing the base with LDA or LiNEt $_{2}$ did not alter the regioselectivity, suggesting that deprotonation at $\mathrm{C}_{13}$ is both kinetically and thermodynamically favored. ${ }^{19}$ Attempts to alkylate the dianion of $\mathbf{1 3}$ were not fruitful. To circumvent this dilemma, we chose to block $\mathrm{C}_{13}$ with a silyl protecting group. ${ }^{20}$ Although TMS and TES groups were found to be too labile under these metallation conditions, the TBS group proved to be suitable. Treatment of 13 with $n$-BuLi followed by addition of TBSOTf led to $\mathrm{C}_{13}$-protected bisoxazole (15) in $96 \%$ yield.

Scheme 3. Preparation of a Hennoxazole Model System
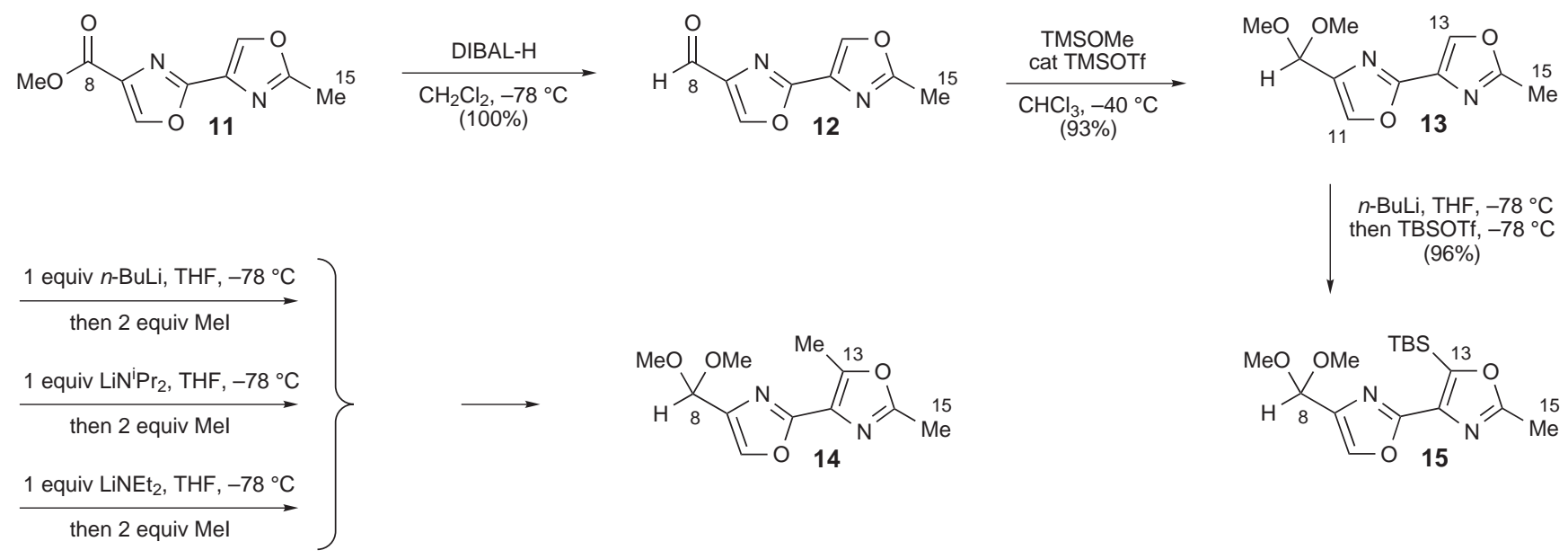

To model our key coupling step, we treated protected bisoxazole (15) with several different strong bases and quenched with MeI (Scheme 4). Gratifyingly, alkylation occurred at the desired $\mathrm{C}_{15}$ site, with $\mathrm{LiNEt}_{2}$ providing the best results. It is interesting to note that $n$-BuLi and LDA both gave poor conversion and small amounts of product 17 -methylated at both at the $\mathrm{C}_{15}$-methyl and $\mathrm{C}_{10}$-ring positions-at the 
expense of starting material conversion. ${ }^{21}$ No significant monomethylation at $\mathrm{C}_{10}$ was observed. We speculate that this result could potentially arise from rate differences of the $\mathrm{C}_{10}$ and $\mathrm{C}_{15}$-anions with respect to alkylation and intermolecular proton exchange. Chelation of lithium between $\mathrm{C}_{10}$ and an oxygen atom of the $\mathrm{C}_{8}$-dimethyl acetal could decrease the reactivity at this center and lead to the observed product mixtures. To better mimic the reactivity of the actual side chain fragment (3), we also alkylated 15 with allyl iodide and prenyl bromide, both of which gave excellent results with $\mathrm{LiNEt}_{2}{ }^{22}$ Finally, treatment of alkylated products (18) and (19) with TBAF demonstrated that the oxazole could be cleanly deprotected under mild conditions. ${ }^{23}$

Scheme 4. Hennoxazole Side Chain Alkylation Model Studies

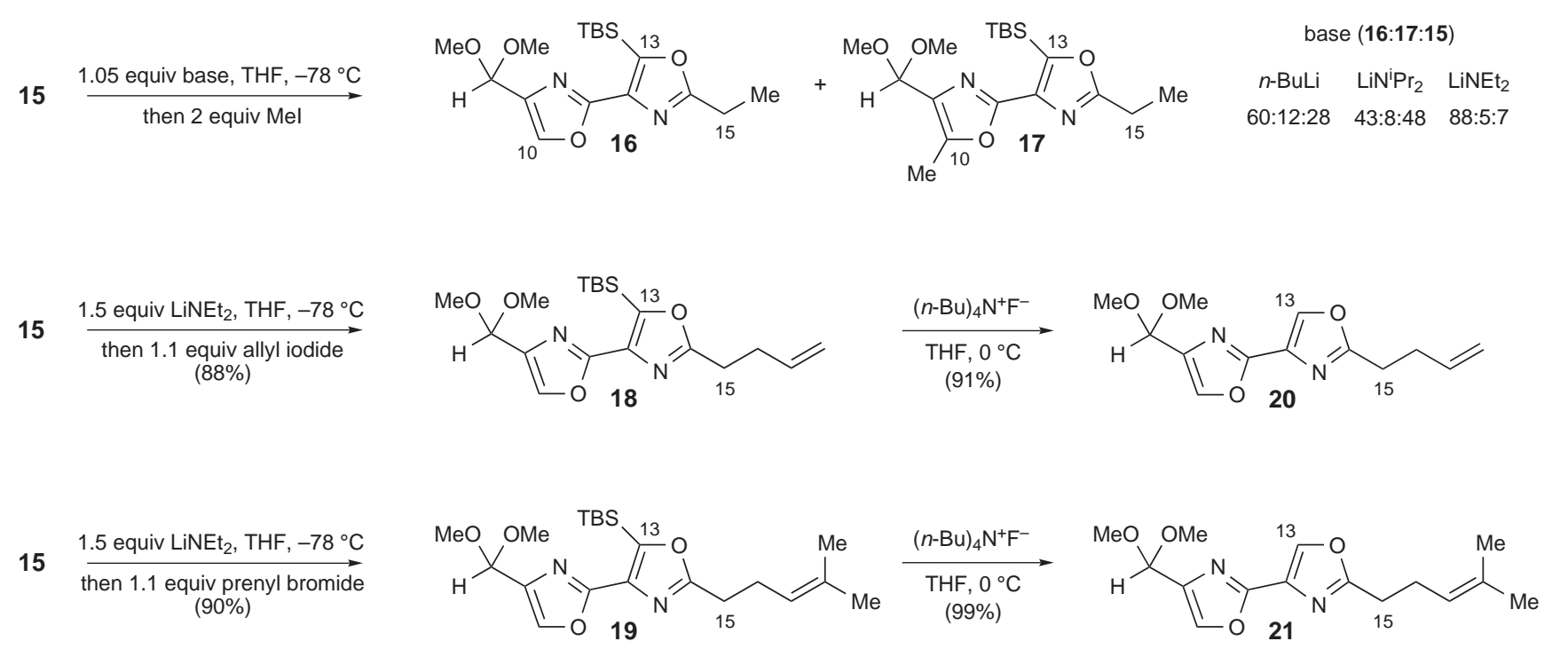

\section{CONCLUSION}

Selective alkylation of a $\mathrm{C}_{8}-\mathrm{C}_{15}$ model for the bisoxazole portion of hennoxazole $\mathrm{A}$ is possible using lithium diethylamide when the $\mathrm{C}_{13}$-position is blocked. Thus, modification of our initial retrosynthetic analysis (Scheme 1) to include a silyl protecting group at $\mathrm{C}_{13}(\mathrm{R}=\mathrm{TBS})$ should provide a successful fragment coupling approach to hennoxazole A. Further reports on this synthesis will be forthcoming.

\section{ACKNOWLEDGEMENTS}

We thank the ACS Petroleum Research Fund (PRF-36453-GB1) and Williams College for financial support. A Pfizer Summer Undergraduate Research Fellowship for EPB is also gratefully acknowledged.

\section{REFERENCES AND NOTES}

1. (a) C. J. Forsyth, F. Ahmed, R. D. Cink, and C. S. Lee, J. Am. Chem. Soc., 1998, 120, 5597. (b) D. A. Evans, D. M. Fitch, T. E. Smith, and V. J. Cee, J. Am. Chem. Soc., 2000, 122, 10033. (c) A. B. Smith, III, K. P. Minbiole, P. R. Verhoest, and M. Schelhaas, J. Am. Chem. Soc., 2001, 123, 10942.

2. (a) P. Wipf and S. Lim, J. Am. Chem. Soc., 1995, 117, 558. (b) D. R. Williams, D. A. Brooks, and M. A. Berliner, J. Am. Chem. Soc., 1999, 121, 4924. (c) F. Yokokawa, T. Asano, and T. Shioiri, 
Tetrahedron, 2001, 57, 6311.

3. J. Li, S. Jeong, L. Esser, and P. G. Harran, Angew. Chem. Int. Ed., 2001, 40, 4765 and references cited therein.

4. S. K. Chattopadhyay and G. Pattenden, J. Chem. Soc., Perkin Trans. 1, 2000, 2429 and references cited therein.

5 (a) A. J. Phillips, Y. Uto, P. Wipf, M. J. Reno, and D. R. Williams, Org. Lett., 2000, 2, 1165. For a review of classical methods of oxazole synthesis see: (b) I. J. Turchi, 'Oxazoles' in 'Heterocyclic Compounds,' Vol. 45, ed. by I. J. Turchi, Wiley, New York, 1986. (c) F. W. Hartner, 'Oxazoles,' in 'Comprehensive Heterocyclic Chemistry II,' Vol. 6, ed. by A. R. Katritzky, C. W. Rees, and E. F. V. Scriven, Pergamon Press, Oxford, 1996, pp. 262-318 and references cited therein.

6. See references 1a, 2a, and 2c. See also: (a) J. C. Muir, G. Pattenden, and R. M. Thomas, Synthesis, 1998, 613. (b) S. K. Chattopadhyay, J. Kempson, A. McNeil, G. Pattenden, M. Reader, D. E. Rippon, and D. Waite, J. Chem. Soc., Perkin Trans. 1, 2000, 2415.

7. For a review of the uses of oxazoles as protected carboxylate equivalents see: H. H. Wasserman, K. E. McCarthy, and K. S. Prowse, Chem. Rev., 1986, 86, 845. See also: references 5b and 5c.

8. See references 1b, 1c, 2b, and 4. See also: (a) P. Liu and J. Panek, Tetrahedron Lett., 1998, 39, 6143 and 6147. (b) C. M. Shafer and T. F. Molinski, J. Org. Chem., 1998, 63, 551. (c) J. V. Schaus and J. S. Panek, Org. Lett., 2000, 2, 469. (d) A. B. Smith, III, K. P. Minbiole, and S. Freeze, Synlett, 2001, 1739.

9. For total syntheses of hennoxazole A, see reference 2. For synthetic studies, see: (a) A. G. M. Barrett and J. T. Kohrt, Synlett, 1995, 415 (b) Z. Cheng, Y. Hamada, and T. Shioiri, Synlett, 1997, 109. (c) T. Shioiri, N. McFarlane, and Y. Hamada, Heterocycles, 1998, 47, 73. (d) A. Vakalopoulos and H. M. R. Hoffmann, Org. Lett., 2001, 3, 177.

10. (a) B. Lipshutz and R. Hungate, J. Org. Chem. 1981, 46, 1410. (b) S. E. Whitney and B. Rickborn, J. Org. Chem., 1991, 56, 3058. (c) E. Vedejs and M. A. Zajac, Org. Lett., 2001, 3, 2451. (d) D. A. Entwistle, S. I. Jordan, J. Montgomery, and G. Pattenden, Synthesis, 1998, 603. (e) D. Garey, M. Ramirez, S. Gonzales, A. Wertsching, S. Tith, K. Keefe, and M. R. Pena, J. Org. Chem., 1996, 61, 4853. (f) J. H. Bowie, P. F. Donaghue, H. J. Rodda, and D. H. Williams, Org. Mass Spectrom., 1968, 1, 13. See also reference 7.

11. (a) G. Knaus and A. I. Meyers, J. Org. Chem., 1974, 39, 1192. (b) A. I. Meyers and J. P. Lawson, Tetrahedron Lett., 1981, 22, 3163. (c) A. I. Meyers and S. Hellring, J. Org. Chem., 1982, 47, 2999.

(d) A. I. Meyers, J. P. Lawson, D. G. Walker, and R. J. Linderman, J. Org. Chem., 1986, 51, 5111.

(e) H. Hamana and T. Sugasawa, Chem. Lett., 1983, 333. For a review of oxazole metallation see:

(f) B. Idon, Heterocycles, 1994, 37, 1321.

12. D. Williams, D. Brooks, and K. Meyer, Tetrahedron Lett., 1998, 39, 8023.

13. D. A. Evans, V. J. Cee, T. E. Smith, and K J. Santiago, Org. Lett., 1999, 1, 87.

14. T. E. Smith, M. S. Mourad, and A. J. Velander, Heterocycles, 2002, 57, xxxx.

15. The carbanion of $\mathbf{9}$ may be delocalized into the $\mathrm{C}=\mathrm{N} \pi$ system.

16. Known ester (11) was prepared in 5 steps following literature procedures. See reference 6b. See 
also: D. R. Williams, P. D. Lowder, Y.-G. Gu, and D. A. Brooks, Tetrahedron Lett., 1997, 38, 331.

17. Aldehyde (12) has been reported, but no preparation conditions are given: D. R. Williams, D. A. Brooks, J. L. Moore, and A. O. Stewart, Tetrahedron Lett., 1996, 37, 983. See reference 23 for spectral data.

18. T. Tsunoda, M. Suzuki, and R. Noyori, Tetrahedron Lett., 1980, 21, 1357. See also reference 8a.

19. Williams carried out semiempirical calculations also suggesting that the ring-lithiated intermediate was thermodynamically favored due to chelation with the adjacent oxazole nitrogen (reference 12).

20. Silylation at $\mathrm{C}_{5}$ was one approach to solving "the oxazole problem" in virginiamycin (a) R. Wood and B. Ganem, Tetrahedron Lett., 1983, 24, 4391. (b) E. Fujita , Heterocycles, 1984, 21, 41.

21. Product identities and ratios were determined using a combination of ${ }^{1} \mathrm{HNMR}$ and GCMS analysis. All isolated yields are following silica gel chromatography. Spectral data for 12-15 and 19-21 are given in reference 23 .

22. Representative Bisoxazole Alkylation Procedure using $\operatorname{LiNEt}_{2}$ : To a solution of diethylamine (22 $\mu \mathrm{L}, 0.213 \mathrm{mmol})$ in THF $(1 \mathrm{~mL})$ at $-78^{\circ} \mathrm{C}$ under Ar was added $n$-butyllithium $(133 \mu \mathrm{L}$ of a $1.5 \mathrm{M}$ hexane solution, $0.199 \mathrm{mmol}$ ) dropwise. After stirring at $-78^{\circ} \mathrm{C}$ for $5 \mathrm{~min}$, warming to $0{ }^{\circ} \mathrm{C}$ for 10 min, and re-cooling to $-78^{\circ} \mathrm{C}$, this solution was added via canula to a solution of bisoxazole (15) ( $48.0 \mathrm{mg}, 0.142 \mathrm{mmol})$ in THF $(1 \mathrm{~mL})$. The resulting bright red solution was stirred at $-78^{\circ} \mathrm{C}$ for 30 min. Allyl iodide $(14.3 \mu \mathrm{L}, 0.156 \mathrm{mmol})$ was added dropwise and the color faded to a light orange. After $15 \mathrm{~min}$, the reaction was quenched with sat. aq. $\mathrm{NaHCO}_{3}(2 \mathrm{~mL})$ and warmed to rt. The resulting mixture was partitioned between $\mathrm{CH}_{2} \mathrm{Cl}_{2}(10 \mathrm{~mL})$ and sat. aq. $\mathrm{NaHCO}_{3}(10 \mathrm{~mL})$. The aqueous layer was extracted with $\mathrm{CH}_{2} \mathrm{Cl}_{2}(2 \times 10 \mathrm{~mL})$, the combined organics were dried over a 1:1 mixture of $\mathrm{K}_{2} \mathrm{CO}_{3}$ and $\mathrm{Na}_{2} \mathrm{SO}_{4}$, filtered, and concentrated in vacuo. The residue was purified by flash chromatography (silica gel deactivated with $2.5 \% \mathrm{Et}_{3} \mathrm{~N}$ ) eluting with 1:4 $\mathrm{Et}_{2} \mathrm{O}$ :hexanes to afford the allylated product $(\mathbf{1 8}, 47.0 \mathrm{mg}, 88 \%)$ as a colorless oil; ${ }^{1} \mathrm{H}$ NMR $\left(\mathrm{CDCl}_{3}\right) \delta 7.68(\mathrm{~d}, J=$ $0.9 \mathrm{~Hz}, 1 \mathrm{H}), 5.84$ (ddt, $J=17.1,10.3,6.5 \mathrm{~Hz}, 1 \mathrm{H}), 5.45$ (d, $J=0.6 \mathrm{~Hz}, 1 \mathrm{H}), 5.06$ (dd, $J=17.1,1.6$ $\mathrm{Hz}, 1 \mathrm{H}) 4.99(\mathrm{dd}, J=10.2,1.3 \mathrm{~Hz}, 1 \mathrm{H}), 3.36(\mathrm{~s}, 6 \mathrm{H}), 2.94(\mathrm{t}, J=7.9 \mathrm{~Hz}, 2 \mathrm{H}), 2.55(\mathrm{dt}, J=7.1,7.8$ $\mathrm{Hz}, 2 \mathrm{H}), 0.93$ (s, 9H), 0.376 (s, 6H) ppm.; ${ }^{13} \mathrm{C} \mathrm{NMR}\left(\mathrm{CDCl}_{3}\right) \delta$ 168.1, 156.8, 155.0, 139.8, 139.1, 136.7, 136.5, 116.1, 98.8, 53.0, 31.2, 27.7, 26.7, 17.8, -5.7 ppm.; IR (neat) 1062, 1103, 1193, 1251, 1391, 1470, 1580, 1612, 2858, $2931 \mathrm{~cm}^{-1}$; Anal. Calcd for $\mathrm{C}_{19} \mathrm{H}_{30} \mathrm{~N}_{2} \mathrm{O}_{4} \mathrm{Si}: \mathrm{C}, 60.29 ; \mathrm{H}, 7.99$; N, 7.40. Found: C, 60.56; H, 8.02; N, 7.37.

23. Spectral data for other new compounds are as follows:

12: ${ }^{1} \mathrm{H}-\mathrm{NMR}\left(\mathrm{CDCl}_{3}, 300 \mathrm{MHz}\right) \delta 10.0(\mathrm{~s}, 1 \mathrm{H}), 8.30(\mathrm{~s}, 1 \mathrm{H}), 8.23$ (s, 1H), 2.57 (s, 3H) ppm.; ${ }^{13} \mathrm{C}-\mathrm{NMR}\left(\mathrm{CDCl}_{3}, 75 \mathrm{MHz}\right) \delta$ 184.3, 163.3, 156.6, 143.7, 141.7, 139.6, 129.7, 14.0 ppm.; IR (neat) 3124, 1686, 1295, $1206 \mathrm{~cm}^{-1}$; Anal. Calcd for $\mathrm{C}_{8} \mathrm{H}_{6} \mathrm{~N}_{2} \mathrm{O}_{3}: \mathrm{C}, 53.94 ; \mathrm{H}, 3.39 ; \mathrm{N}, 15.73$. Found: C, $54.08 ; \mathrm{H}, 3.45 ; \mathrm{N}, 15.70$.

13: ${ }^{1} \mathrm{H}-\mathrm{NMR}\left(\mathrm{CDCl}_{3}, 300 \mathrm{MHz}\right) \delta 8.08(\mathrm{~s}, 1 \mathrm{H}), 7.64(\mathrm{~s}, 1 \mathrm{H}), 5.38(\mathrm{~s}, 1 \mathrm{H}), 3.30(\mathrm{~s}, 6 \mathrm{H}), 2.45(\mathrm{~s}, 3 \mathrm{H})$ ppm.; ${ }^{13} \mathrm{C}-\mathrm{NMR}\left(\mathrm{CDCl}_{3}, 75 \mathrm{MHz}\right) \delta 162.8,155.7,139.7,138.5,137.0,130.6,98.6,53.1,14.0$ 
ppm.; IR (neat) 3119, 1636, 1530, 1305, 1106, 1058, $984 \mathrm{~cm}^{-1}$; Anal. Calcd for $\mathrm{C}_{10} \mathrm{H}_{12} \mathrm{~N}_{2} \mathrm{O}_{4}$ : C, 53.57; H, 5.39; N, 12.49. Found: C, 53.68; H, 5.41; N, 12.41.

14: ${ }^{1} \mathrm{H}-\mathrm{NMR}\left(\mathrm{CDCl}_{3}, 300 \mathrm{MHz}\right) \delta 7.66(\mathrm{~d}, J=0.8 \mathrm{~Hz}, 1 \mathrm{H}), 5.43(\mathrm{~s}, J=0.8 \mathrm{~Hz}, 1 \mathrm{H}), 3.35(\mathrm{~s}, 6 \mathrm{H})$, 2.60 (s, 3H), 2.43 (s, 3H) ppm.; ${ }^{13} \mathrm{C}-\mathrm{NMR}\left(\mathrm{CDCl}_{3}, 75 \mathrm{MHz}\right) \delta 160.3,156.7,149.9,139.5,136.4$, 125.2, 98.7, 53.0, 13.8, 11.7 ppm.; IR (neat) 2937, 1593, 1197, 1097, 1055, $980 \mathrm{~cm}^{-1}$; Anal. Calcd for $\mathrm{C}_{11} \mathrm{H}_{14} \mathrm{~N}_{2} \mathrm{O}_{4}$ : C, 55.46; H, 5.92; N, 11.76. Found: C, 55.57; H, 5.97; N, 11.66 .

15: ${ }^{1} \mathrm{H}-\mathrm{NMR}\left(\mathrm{CDCl}_{3}, 300 \mathrm{MHz}\right) \delta 7.69(\mathrm{~d}, J=0.9 \mathrm{~Hz}), 5.45(\mathrm{~d}, 1 \mathrm{H}, J=0.9 \mathrm{~Hz}), 3.37$ (s, 6H), 2.53 (s, 3H), 0.94 (s, 9H), 0.38 (s, 6H) ppm.; ${ }^{13} \mathrm{C}-\mathrm{NMR}\left(\mathrm{CDCl}_{3}, 75 \mathrm{MHz}\right) \delta 165.3,156.8,155.0,139.9$, 139.2, 136.7, 98.8, 53.0, 26.7, 17.8, 14.0, -5.7 ppm.; IR (neat) 2929, 1611, 1114, 1101, $1061 \mathrm{~cm}^{-1}$; Anal. Calcd for $\mathrm{C}_{16} \mathrm{H}_{26} \mathrm{~N}_{2} \mathrm{O}_{4} \mathrm{Si}$ : C, 56.78; H, 7.74; N, 8.28. Found: C, 56.98; H, 7.67; N, 8.29.

19: ${ }^{1} \mathrm{H}-\mathrm{NMR}\left(\mathrm{CDCl}_{3}, 300 \mathrm{MHz}\right) \delta 7.68(\mathrm{~d}, J=0.9 \mathrm{~Hz}, 1 \mathrm{H}), 5.45(\mathrm{~d}, J=0.9 \mathrm{~Hz}, 1 \mathrm{H}), 5.13(\mathrm{t}, J=$ $7.1 \mathrm{~Hz}, 1 \mathrm{H}), 3.36(\mathrm{~s}, 3 \mathrm{H}), 2.85(\mathrm{t}, J=7.3 \mathrm{~Hz}, 2 \mathrm{H}), 2.4(\mathrm{dt}, J=7.4,7.4 \mathrm{~Hz}, 2 \mathrm{H}), 1.66(\mathrm{~s}, 3 \mathrm{H}), 1.56$ (s, 3H), 0.93 (s, 9H), 0.37 (s, 6H) ppm.; ${ }^{13} \mathrm{C}-\mathrm{NMR}\left(\mathrm{CDCl}_{3}, 75 \mathrm{MHz}\right) \delta 168.5,156.9,154.8,139.8$, $139.1,136.7,133.6,122.4,98.8,52.9,28.5,26.6,25.9,25.8,17.82,17.79,-5.7$ ppm.; IR (neat) 2954, 2930, 1469, 1251, 1104, 1062, 843, $124 \mathrm{~cm}^{-1}$; Anal. Calcd for $\mathrm{C}_{21} \mathrm{H}_{34} \mathrm{~N}_{2} \mathrm{O}_{4} \mathrm{Si}$ : C, 62.03; $\mathrm{H}$, 8.43; N, 6.89. Found: C, 62.17; H, 8.56; N, 6.94.

20: ${ }^{1} \mathrm{H}-\mathrm{NMR}\left(\mathrm{CDCl}_{3}, 300 \mathrm{MHz}\right) \delta 8.17(\mathrm{~s}, 1 \mathrm{H}), 7.71(\mathrm{~d}, J=1.0 \mathrm{~Hz}, 1 \mathrm{H}), 5.84(\mathrm{ddt}, J=17.1,10.3$, $6.5 \mathrm{~Hz}, 1 \mathrm{H}), 5.47(\mathrm{~d}, J=1.0,1 \mathrm{H}), 5.08(\mathrm{ddt}, J=17.1,3.2,1.6 \mathrm{~Hz}, 1 \mathrm{H}), 5.02(\mathrm{ddt}, J=10.2,2.8,1.2$ $\mathrm{Hz}, 1 \mathrm{H}), 3.38(\mathrm{~s}, 3 \mathrm{H}), 2.93(\mathrm{t}, J=7.2 \mathrm{~Hz}, 2 \mathrm{H}), 2.58(\mathrm{dt}, J=6.6,6.6 \mathrm{~Hz}, 2 \mathrm{H}) \mathrm{ppm}$; ${ }^{13} \mathrm{C}-\mathrm{NMR}$ $\left(\mathrm{CDCl}_{3}, 75 \mathrm{MHz}\right) \delta 165.6,155.8,139.8,138.5,137.1,136.3,130.5,116.4,98.6,53.1,30.1,27.8$ ppm.; IR (neat) 2939, 1103, 1059, 984, $916 \mathrm{~cm}^{-1}$; Anal. Calcd for $\mathrm{C}_{13} \mathrm{H}_{16} \mathrm{~N}_{2} \mathrm{O}_{4}$ : C, 59.08; H, 6.10; N, 10.60. Found: C, 58.94; H, 6.16; N, 10.46 .

21: ${ }^{1} \mathrm{H}-\mathrm{NMR}\left(\mathrm{CDCl}_{3}, 300 \mathrm{MHz}\right) \delta 8.16(\mathrm{~s} 1 \mathrm{H}), 7.70(\mathrm{~d}, J=0.9 \mathrm{~Hz}, 1 \mathrm{H}), 5.46(\mathrm{~d}, J=0.8 \mathrm{~Hz}, 1 \mathrm{H})$, $5.11(\mathrm{t}, J=7.1 \mathrm{~Hz}, 1 \mathrm{H}), 3.74(\mathrm{~s}, 6 \mathrm{H}), 2.83(\mathrm{t}, J=7.3 \mathrm{~Hz}, 2 \mathrm{H}), 2.48(\mathrm{dt}, J=7.4,6.8 \mathrm{~Hz}, 2 \mathrm{H}), 1.66$ (s, 3H), 1.58 (s, 3H) ppm.; ${ }^{13} \mathrm{C}-\mathrm{NMR}\left(\mathrm{CDCl}_{3}, 75 \mathrm{MHz}\right) \delta 166.0,155.8,139.7,138.4,137.0,133.9$, 130.4, 122.0, 98.6, 53.0, 28.5, 25.8, 25.7, 17.8 ppm.; IR (neat) 2933, 1103, 1059, $984 \mathrm{~cm}^{-1}$; Anal. Calcd for $\mathrm{C}_{15} \mathrm{H}_{20} \mathrm{~N}_{2} \mathrm{O}_{4}:$ C, 61.63; H, 6.90; N, 9.58. Found: C, 61.38; H, 7.06; N, 9.36. 